Received: October 12, 2017

Revision received: March 21, 2018

\title{
Collaborative Innovation of Ideological and Political Education in Colleges and Universities Based on Philosophical Cognitive Thinking
}

\author{
Defang Guan ${ }^{1}$ \\ Liaoning Normal University
}

\begin{abstract}
This paper attempts to study the ideological and political education in colleges and universities from the perspective of philosophical cognitive thinking by analyzing the influences of philosophical cognitive thinking on college ideological and political education and the relationship between the two. In addition to analyzing the influences of new media on ideological and political education in colleges and universities, this paper also proposes innovative thinking in building ideological and political education platforms, enriching educational content and improving educational methods. Through the above analysis, it is concluded that efforts should be made to build a healthy network environment, cultivate quality education teams and establish characteristic netplatforms based on philosophical cognitive thinking as the new ways to innovate ideological and political education in colleges and universities.
\end{abstract}

\section{Keywords}

New Media $\bullet$ Colleges and Universities • Ideological and Political Education • Innovative Measures

\footnotetext{
${ }^{1}$ Correspondence to: Defang Guan (PhD), School of Marxism, Liaoning Normal University, Dalian 116029, China. Email: $82918869 \mathrm{gg} @$ sina.com

Citation: Guan, D.F. (2018). Collaborative Innovation of Ideological and Political Education in Colleges and Universities Based on Philosophical Cognitive Thinking. Educational Sciences: Theory \& Practice, 18(5), 1722-1729. http://dx.doi.org/10.12738/estp.2018.5.071
} 
Effective approaches to ideological and political education research are the most important subject for college teachers (Lee, 2012). With the rapid development of the network information era, networks have become an indispensable part of our life, work and study. Networks have brought a colourful world to students together with certain negative impacts ( $\mathrm{Li}, 2018)$. The new media is a form of media based on Internet, mobile communication and digital technology, which provides readers with information and related services via some common terminals. With the help of various devices and applications, the new media, due to its vast information flow, portable use and good human-computer interaction experience, has become the main form of information acquisition and communication among students in colleges and universities (Vandsburger, DuncanDaston, Akerson \& Dillon, 2010; Garcia \& Jager 2011). In this context, it has become a mainstream choice in many universities and colleges to conduct ideological and political education through the new media. The pattern of undergraduate political education in colleges and universities is shown in Figure 1.

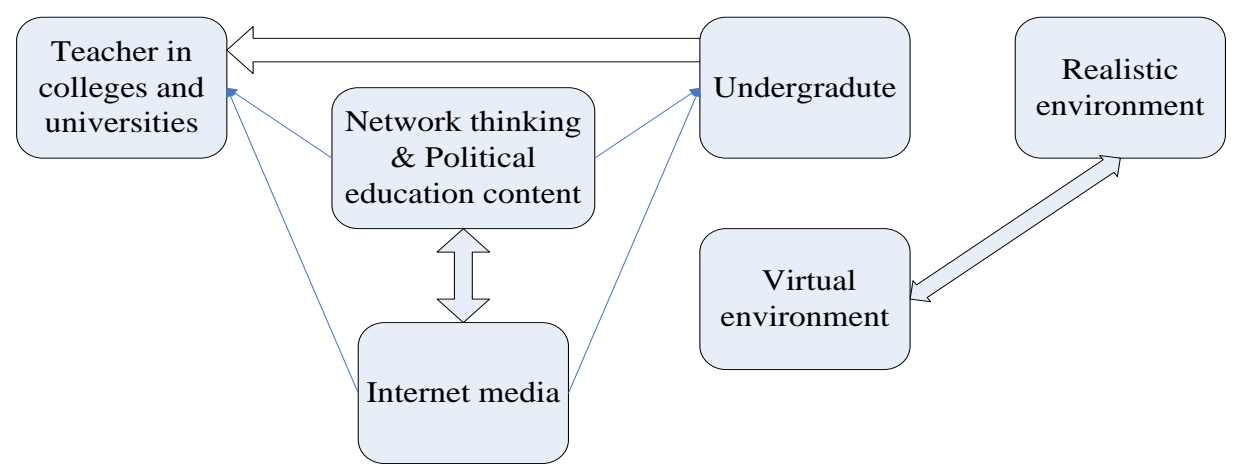

Figure 1. Life mode of network thinking and undergraduate political education in colleges and universities.

With this trend, the ideological and political education in colleges and universities has undergone tremendous changes in terms of educational resources and teaching means, carriers and approaches. At present, the discussion on the innovation of ideological and political education in colleges and universities is mainly about how to explore and utilize philosophical cognitive thinking on the technical level and apply it to the ideological and political education.

\section{The Influence of Philosophical Cognitive Thinking on the Function of College Ideological and Political Education}

Philosophical cognitive thinking plays a multi-faceted role in ideological and political education. It is very important for us to recognize both its positive and negative aspects when it comes to ideological and political education (Ward, 2001). Figure 2 shows the core themes of cognitive philosophy - cognitive development, cognitive model and cognitive representation, which are divided and integrated from the dynamic, representation and simulation dimensions. 


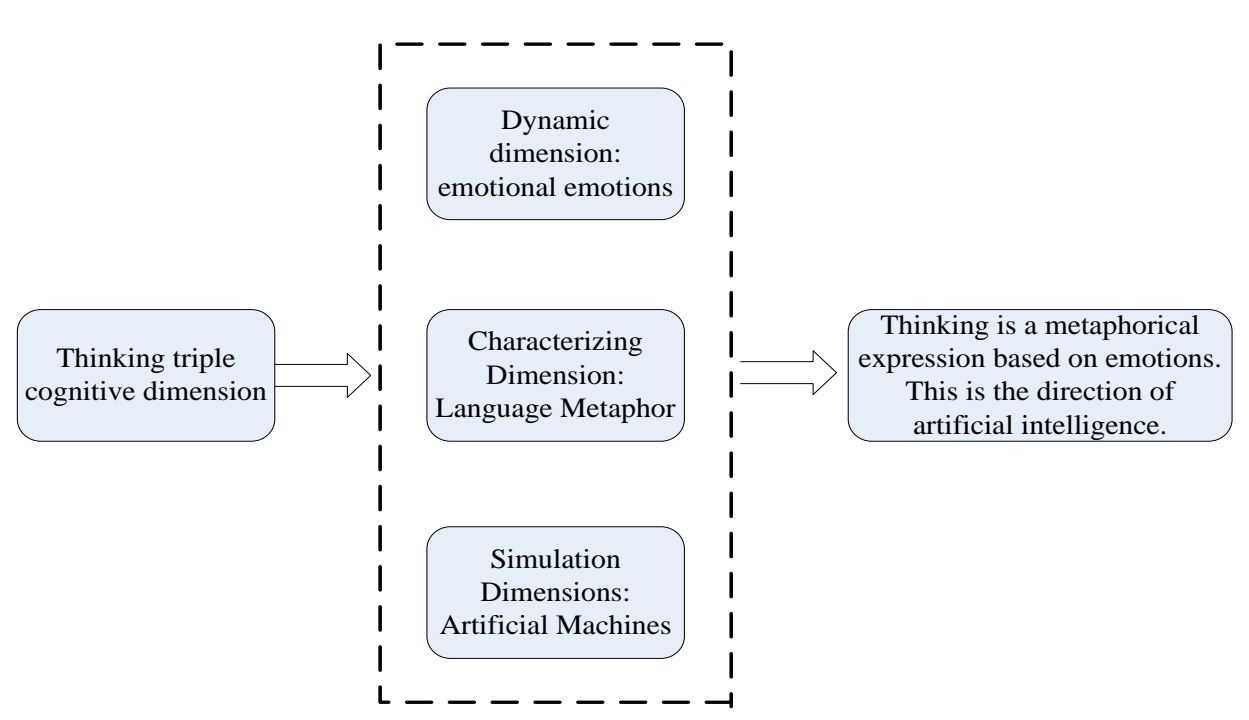

Figure 2. Threefold division of thinking around cognitive philosophy.

On the one hand, philosophical cognitive thinking is the new carrier of ideological and political education in colleges and universities. Its interactivity and equality as well as its efficient and compatible means of communication can enhance the communication between teachers and students, avoid one-way education, and gradually help form a multi-agent communication model. This can fully stimulate students' enthusiasm for learning and make them actively participate in relevant educational activities, so that ideological and political education can fully achieve its expected results (Xu \& Xu, 2017). For example, it allows students to express personal opinions on major social issues during free discussions and to comment or debate on some hot topics. This can help students resonate with positive ideas and thus extend the results of ideological and political education. The cognitive development stage and its corresponding scores are shown in Table 1.

Table 1

The Stage of Cognitive Development and Corresponding Scores

\begin{tabular}{lcccc}
\hline $\begin{array}{l}\text { Cognitive } \\
\text { development } \\
\text { stage }\end{array}$ & $\begin{array}{c}\text { Specific } \\
\text { operation } \\
\text { stage }\end{array}$ & $\begin{array}{c}\text { Specific operation phase } ~ \\
\text { form operation transition } \\
\text { phase }\end{array}$ & $\begin{array}{c}\text { Initial stage of } \\
\text { formal operation }\end{array}$ & $\begin{array}{c}\text { Formal } \\
\text { operation stage }\end{array}$ \\
\hline $\begin{array}{l}\text { Corresponding } \\
\text { score }\end{array}$ & $<5$ & $16 \sim 20$ & $21 \sim 22$ & $>23$ \\
\hline
\end{tabular}

On the other hand, there are also differences in humanistic logic between ideological and political education and other methods. Specifically, some methods focus more on the economics of an enterprise, of which the purpose is to meet the needs of consumers and achieve optimal configuration. Humanistic education in colleges and universities mainly emphasizes the cultivation of students in value systems, ways of thinking and habits. Its essence is not to cater to, but to guide the students and respect their autonomies (Chen, Lu, \& Liu,2018). In this regard, other methods inevitably conflict with ideological and political education. Therefore, how to play the advantages and reduce the disadvantages has become the focus of educators. Figure 3 is a 3D pattern of cognitive thinking. 


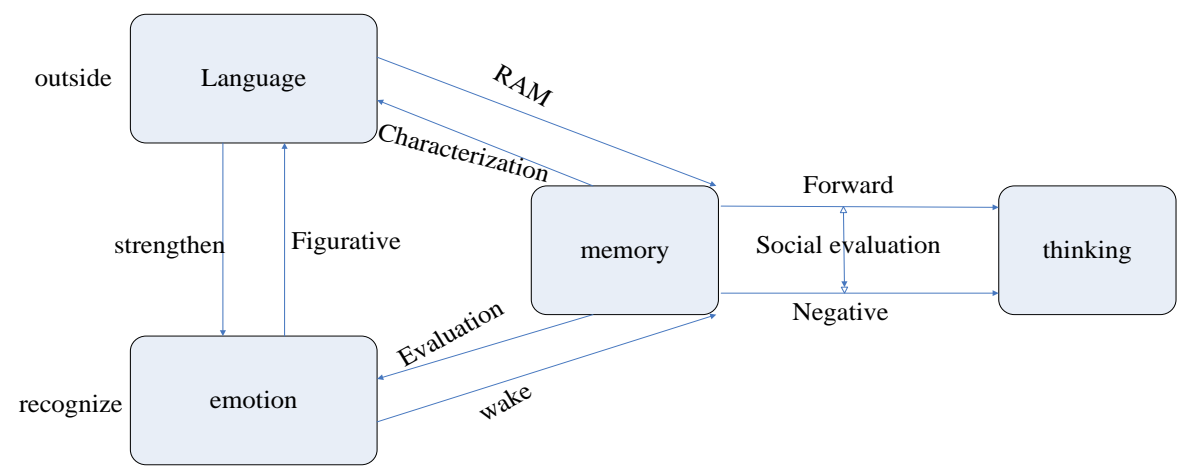

Figure 3. Three-Dimensional Operational Diagram of Cognitive Thinking.

In general, philosophical cognitive thinking provides new requirements for the development of ideological and political education in colleges and universities and also brings subtle influences on the values, ways of thinking, political view and moral standards of college and university students. Ideological and political education in colleges and universities is carried out to further improve the ideological and political quality of college students; however, many colleges and universities still use traditional methods and ideas. In order to solve this problem, educators should focus on the key issues and start with renewing the educational concepts. In addition, regarding the teaching method, it is necessary to organically combine the new model with the traditionally accepted and effective methods to form a new image of ideological and political education, and play its due role in education.

\section{Viewing the innovative methods of ideological and Political Education in Colleges and Universities from the Angle of Philosophical Cognitive Thinking}

\section{Enrich the contents of ideological and political education in colleges and universities}

To enrich the content of the ideological and political education platform, three aspects should be considered. Firstly, with the development of information technology and the popularity of mobile networks, the content of ideological and political education in colleges and universities should be fully networked, not just limited to oral teaching and teaching materials. Information can be provided online in a way that is suitable for network communication only through network conversion of related content. Only in this way can ideological and political education complete the new-media-oriented development and fully adapt to the new characteristics of the times. Secondly, in view of college students' increasing attention to social hotspots, colleges and universities should have overall understanding of online public opinions and make rigorous responses to important issues in a timely manner. At the same time, colleges and universities should promptly refute extreme and even wrong views and guide students to have an objective and comprehensive understanding of the problems. This will help 
college students gradually form relatively correct values through the discussion and exchange of ideas on hot issues. Finally, colleges and universities can adopt some methods to train students' academics abilities, like using proper national textbooks. While using textbooks and materials, teachers can incorporate some social hot topics or problems into classroom teaching to make the teaching content more profound and hierarchical. This is the only way to promote the exchange of information between colleges/universities and students, eliminate the gaps in ideological exchanges and ensure the smooth development of ideological and political education. Figure 4 shows the cognitive level distribution of the samples in this study.

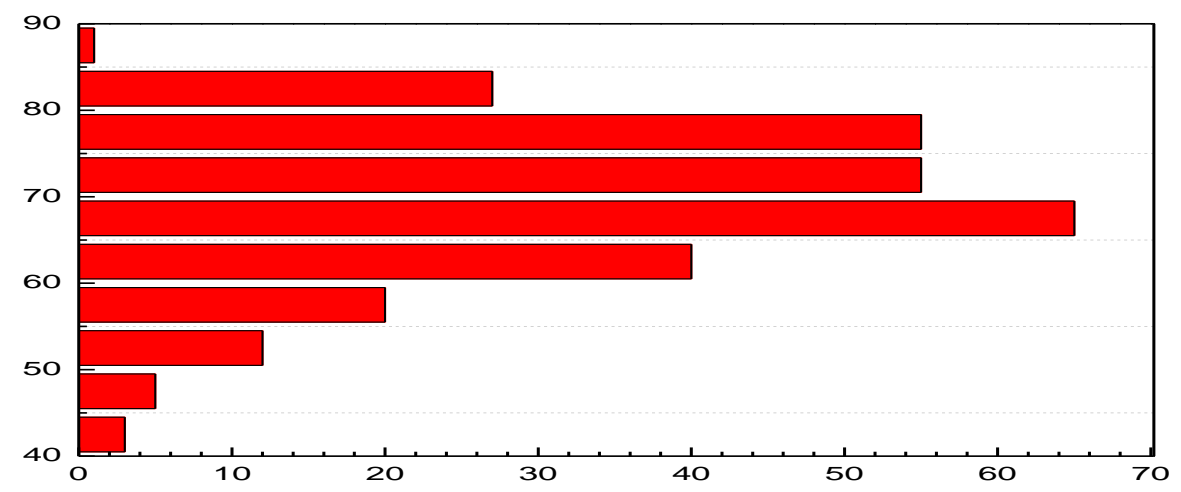

Figure 4. Study the sample's metacognitive level.

\section{Innovative Methods of Ideological and Political Education in Colleges and Universities}

In this era of information explosion, college students are already changing from passively receiving information to actively searching for it; in other words, college students have relatively high autonomy when acquiring and processing information. The ideological and political education in colleges and universities should respect the independent thinking of students in such a large environment. In practice, teachers should take a new fair and objective attitude, adopt new educational methods, attract students' attention and help them realize that the traditional one-way ideological and political education model has already changed. In the process, they will also understand that their leading roles are being gradually recognized. At the same time, colleges and universities should pay more attention to cultivating students' independence so that students can correctly acquire and exchange information. The cognitive dynamics relationship is shown in Figure 5. Figure 6 shows the impacts of cognitive levels.

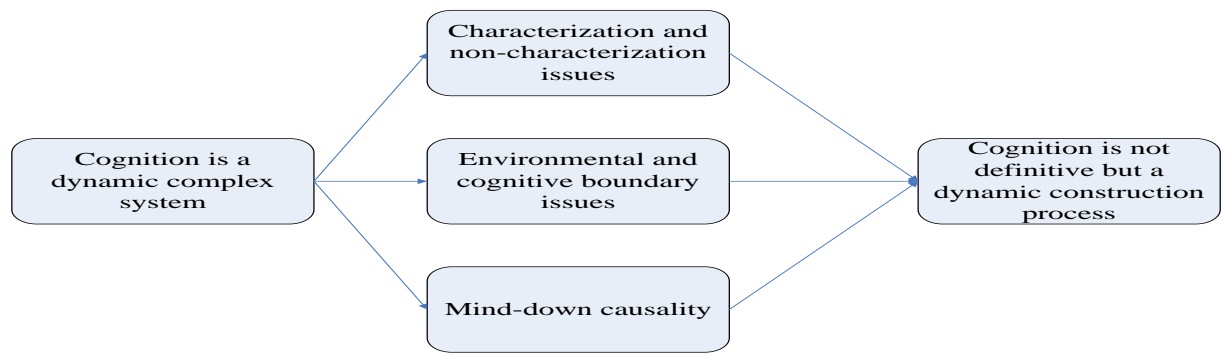

Figure 5. Cognitive Dynamics Diagram. 


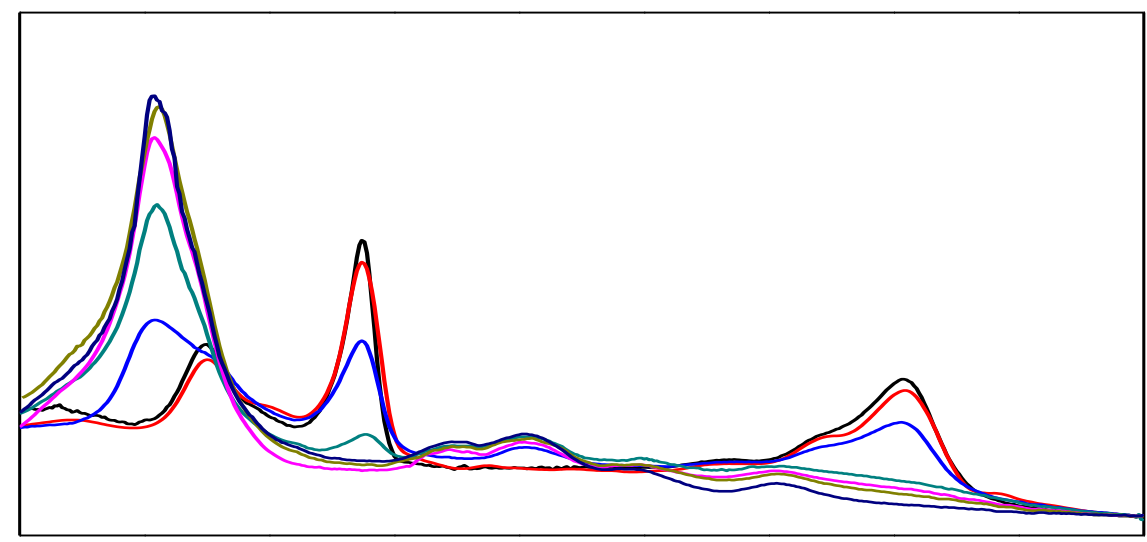

Figure 6. Influence of cognitive level.

\section{Improve the quality of ideological and political education personnel in universities and optimize the working mechanism}

At present, the ideological and political education in colleges and universities puts increasing higher requirements on the overall quality of the education team. The application of philosophical cognitive thinking requires teachers to have high professional competence and a relatively complete specialized knowledge system. Therefore, to implement ideological and political education in colleges and universities, there should be a professional education team in place. However, many students lack proper understanding of ideological and political education and are not sensitive to its content, which directly affects the effectiveness of ideological and political education.

Colleges and universities can carry out ideological and political education from two aspects - constructing the work system and improving the quality of the education team. In terms of the work system construction, colleges and universities should fully consider the rationality of the existing ideological and political education frameworks, organize relevant personnel to establish a collaborative innovation research team for incorporating philosophical cognitive thinking into ideological and political education, integrate all resources into the content of ideological and political education and transform theories into applications. This can enhance students' interest in learning relevant content and enable them to establish a series of campus organizations based on their own strengths so as to achieve their self-management and self-education. Figure 7 shows the basic structure of the philosophical-thinking-based innovative mechanism of ideological and political education in colleges and universities.

First, students' initiatives are actively promoted. The purpose of quality development training is to stimulate students' subjective initiatives, enable students to change their motivations during the teaching process and allow them to actively learn. Through quality development training, students can effectively achieve independent learning and students and teachers will have a free and relaxed environment where they can effectively communicate with each other. Through the implementation of quality development training, the 
teaching content is incorporated into the practical training, increasing students' enthusiasm for learning. This method is very good for students who accept ideological and political education and effective in improving students' comprehensive quality.

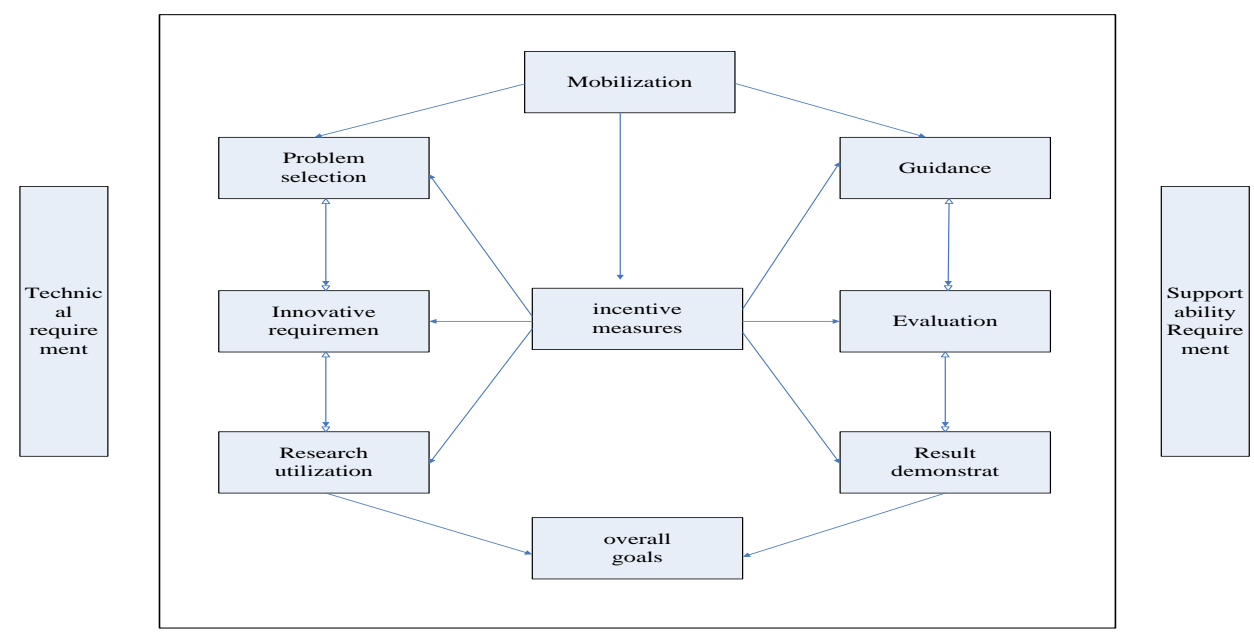

Figure 7. Demonstrate the basic structure of the philosophical thought to study the construction of innovative mechanism of ideological and political education in colleges.

Second, a proper teaching scenario is created. Through further quality development training in ideological education, a more relaxed learning environment is created for students, which can effectively improve their ideological and political level. Also, through quality development training and related activities, students are able to experience the importance of political teaching, which is of great significance to improving the quality of ideological and political education.
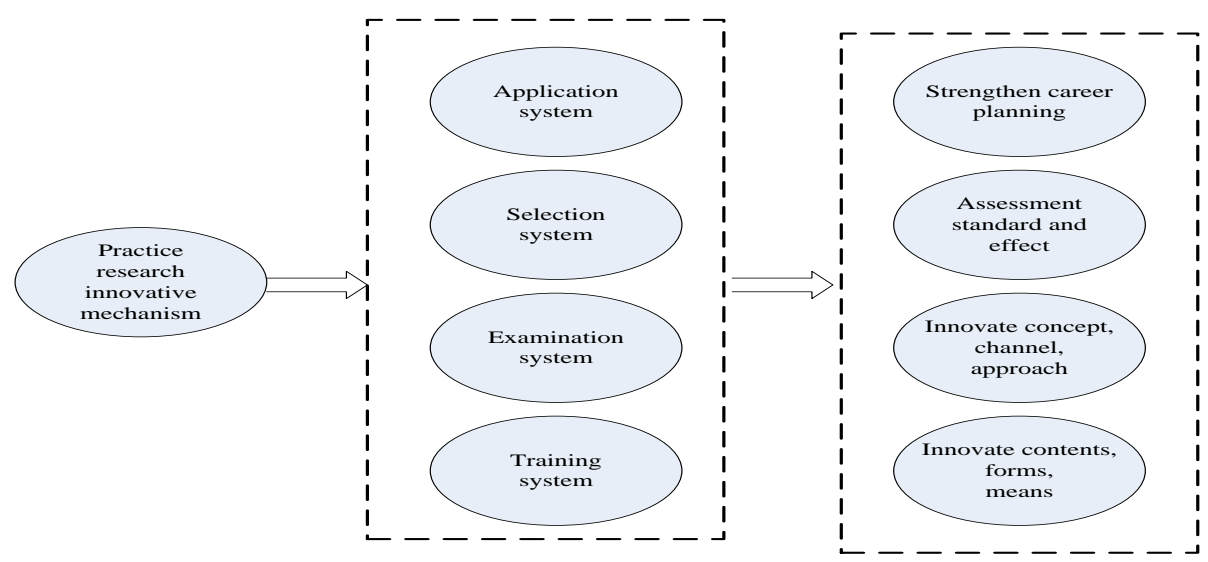

Figure 8. Schematic diagram of collaborative innovation mechanism. 
Third, students' hands-on skills are also trained. Through quality development training, students can not only learn relevant ideological and political knowledge, but also develop their own hands-on skills, thus further improving their comprehensive quality. Figure 8 shows the collaborative innovation research mechanism.

\section{Conclusions}

With the social development, people are having more profound understanding of ideological and political education. Therefore, in the actual teaching process, we must constantly innovate teaching methods and actively expand the content of ideological and political teaching based on the characteristics of contemporary philosophical cognitive thinking. Only in this way can we shorten the distance between teachers and students and improve the efficiency and quality of ideological and political education in colleges and universities. In addition, we should build a healthy network environment, cultivate quality education teams and establish characteristic network platforms based on philosophical cognitive thinking as the new ways to innovate ideological and political education in colleges and universities.

\section{References}

Chen, M. C., Lu, S.Q., \& Liu, Q.L. (2018). Global regularity for a 2D model of electro-kinetic fluid in a bounded domain. Acta Mathematicae Applicatae Sinica, English Series, 34(2), 398-403. http://dx.doi.org/10.1007/s10255-018-0740-3

Garcia, R., \& Jager, W. (2011). From the special issue editors: agent-based modeling of innovation diffusion. Journal of Product Innovation Management, 28(2), 148-151. https://dx.doi.org/10.1111/j.15405885.2011.00788.x

Lee, C. Y. (2012). Learning-by-doing in R\&D, knowledge threshold, and technological divide. Journal of Evolutionary Economics, 22(1), 109-132. http://dx.doi.org/10.1007/s00191-010-0202-4

Li, F. F. (2018). Research Method Innovation of College Students' Ideological and Political Education Based on Cognitive Neuroscience. NeuroQuantology, 16(5), 1303-1306. https://doi.org/ 10.14704/nq.2018.16.5.1269

Vandsburger, E., DuncanDaston, R., Akerson, E., \& Dillon, T. (2010). The effects of poverty simulation, an experiential learning modality, on students' understanding of life in poverty. Journal of Teaching in Social Work, 30(3), 300-316. http://dx.doi.org/10.1080/08841233.2010.497129

Ward, S. B. (2001). Intern supervision in school psychology: practice and process of field-based and university supervisors. School Psychology International, 22(3), 269-284. https://dx.doi.org/ 10.1177/0143034301223004

Xu, Y. F., \& Xu, J. X. (2017). On China's excellent traditional culture and innovation of ideological and political education in colleges and universities. Advances in Social Science, Education and Humanities Research, 106(24), 230-234. https://dx.doi.org/ 10.2991/icesem-17.2017.51 